\title{
YORUBA CULTURE AND LEADERSHIP STYLE IN NIGERIAN ORGANISATION
}

\author{
Bello Deva Vincent ${ }^{1 *}$ and Osarumwense V. Iguisi ${ }^{2}$ \\ ${ }^{1}$ Department of Management Technology, Modibbo Adama University of Technology, Yola, \\ Nigeria \\ ${ }^{2}$ Department of Human Resource Management, University of Benin, Benin City, Nigeria \\ devabvincent@gmail.com \\ Osaru.iquisi@uniben.edu
}

\begin{abstract}
Culture and leadership research in the last decade witnessed a general upsurge. Empirical studies that determined the scores of the subgroup cultures and examined leadership styles and preferences in Nigeria, have not been exhaustively carried out. This study therefore examined subgroup cultures and leadership styles in Nigerian organizations. Due to the structure of most Nigerian public organizations which are characterized by multi-ethnic groups with heterogeneous cultural beliefs, this study examined the differences in the Hofstede's culture dimensions' scores, leadership styles and preferences among Yoruba subgroup in Nigeria with focus on Power Distance and Individualism/Collectivism. Survey research design was adopted, making use of questionnaire for data collection. The study made use of 345 members of staff purposively selected from among the Yoruba subgroups in the Central Bank of Nigeria Headquarters in Abuja. The data generated from the structured questionnaire were analyzed using Statistical Package for Social Science (SPSS) for descriptive statistics. Hofstede's culture dimensions of power distance and individualism/collectivism were computed using the Value Survey Module (VSM) developed by Hofstede. This study found that there is a high power distance among the Yoruba subgroup, and the leadership style preferred by the Yoruba's is the democratic style of leadership and that the Yoruba subgroup is a collectivistic society.
\end{abstract}

Keywords: Leadership Styles, Subgroup, Power Distance, Individualism, Collectivism.

JEL classification: M12, M14, M50, M54.

\section{Introduction}

Culture plays a vital role in an organization and has impact on techniques of motivation, performance management, workplace leadership styles and other management practices in organization.

According to Iguisi (1994), culture influences management practices mainly through motivation, respect, reward system, promotion, and authority. To explain the consequences of culture for management, Hofstede (1980, 1991, 1997 and 2010) developed an empirical model labeled 6-dimensions of cultures namely power distance, which is the degree of inequality that exists in a society (Power are not distributed evenly); individualism/collectivism, Individualism refers to a loosely knit social framework in a society in which people are supposed to take care of themselves and their immediate families only. Collectivism occurs when there is a tight social framework in which people distinguish between in-groups and out-groups - they expect their in-groups (relatives, organizations) to look after them in exchange for absolute loyalty; Uncertainty AvoidanceThis is the extent to which a society feels threatened by uncertain or ambiguous situations; Masculinity/Femininity, Masculinity here, is the extent to which the dominant values are

* Corresponding author: Bello Deva Vincent 
assertiveness, money, heroism and other things (achievement and Success). In this society women are more emphatic and competitive. The other end of the spectrum is the femininity (relationship) which represents a preference for cooperation, modesty, caring for the weak and quality of life: Long-term versus Short-term Orientation formerly called Confucian Dynamism which describes society time horizon; and Indulgence versus Restraint which is the extent to which members of a society try to control their desires and impulses. These dimensions provide a framework for understanding cultural variations in managerial context.

\subsection{Research Questions}

1. What are the scores of Yoruba subgroup in Hofstede's dimension of power distance?

2. What are the scores of Yoruba subgroup in Hofstede's dimension of Individualism/Collectivism?

3. Which leadership style is perceived to be the most dominant among they Yoruba sub- group within the studied Nigerian organization?

4. Which leadership style would the Yoruba subgroup prefer and highly reject in their organization?

\subsection{Objectives of the Study}

1. To determine the scores of the Yoruba subgroup of in Hofstede dimension of power distance;

2. To determine the scores of the Yoruba subgroup in Hofstede dimension of individualism/collectivism;

3. To ascertain the leadership styles perceived to be the most dominant among the Yoruba subgroup within the studied Nigerian organization; and

4. Examine the leadership styles that the Yoruba subgroup cultures prefer and has highly rejected in their organizations.

\section{Review Of Related Literature}

Iguisi (2009) defined culture as the pool of rules, beliefs, and values by which individual or group members conceptually order the objects and events in their lives in order to operate in a manner that is acceptable to people identifying with them and people that are negotiating with them in the course of their interaction. Geert Hofstede $(1980,2010)$ categorizes culture into two namely: "culture one and two". He defines "culture one" as manifested in music, painting, dances, art, folklore, and literature. Hofstede defines "culture two" as the "software of the mind", a collective phenomenon, shared with the people who live in the same social environment. It is the collective programming of the mind, which distinguishes the members of one social group or category of people from another (Hofstede, 1991:p.5). Culture consists of the patterns of thinking of leaders to their followers, and followers to their leaders (Hofstede, 1984).

A subgroup is a collection of people who identify themselves as members of a group that is also part of a larger social system to which they belong (Makama, 2013). It is a small group of people who form part of a larger group. Subgroups exist within a dominant culture and are dependent on that culture. One important subgroup category is occupation, Where most people dress alike, share a common vocabulary and similar values, and are in frequent communication.

Yoruba people live mostly in South-western Nigeria. They have developed a variety of different artistic forms including pottery, weaving, beadwork, metalwork, and mask making (Makama, 2013). The Yoruba's originated from lle-Ife, arose and became quite popular by their trading with the Portuguese. In the late 1800s, the Yoruba's formed a treaty with the Fulani (after the Fulani invasion) and in 1901 they were colonized by the British (Aluko, 
2003). The Yoruba constitute approximately 21 percent of Nigeria's total population. The acceptance of both Christianity and Islam in great proportion could be evidence that the Yoruba's are open minded and ready for adventure. Hence, Yoruba's are largely collective (Aluko, 2003).

Culturally, the Yoruba subordinate shows high respect and regards to his superior. The leadership pattern in this subgroup has low power distance as the organization is characterized with consultative and participative leadership styles.

\subsection{Likert's Leadership Theory}

Likert's leadership styles are leadership styles developed by Rensis Likert in the 1960s. He outlined four systems of management to describe the relationship, involvement, and roles of managers and subordinates in industrial settings. Rensis Likert (1967) leadership styles includes:

Style I: Exploitative-authoritative (Autocratic)- In this system, managers tend to use threats, fear, and punishment to motivate their workers. Managers at the top of the hierarchy make all of the decisions and are usually unaware of the problems faced by those in the lower levels of the organization. Decisions are imposed on subordinates, and motivation is characterized by threats. The orders issued from the top make up the goals for the organization. As a result, workers tend to be hostile toward organizational goals and may engage in behavior that is counter to those goals. This style has no confidence and trust in subordinates. It relies on centralized decision making from the top of the organization. Subordinates are not involved in any important decision making. Downward communication is the main means of transmitting information within the organization in this style.

Style II: Paternalistic-Authoritative- Less controlling than the exploitative authoritative system, under this system motivation is based on the potential for punishment and partially on rewards. The decision making area is expanded by allowing lower-level employees to be involved in policy-making but is limited by the framework given to them from upper-level management. Major policy decisions are still left to those at the top, who have some awareness of the problems that occur at lower levels. This creates mainly downward communication from supervisors to employees with little upward communication, causing subordinates to be somewhat suspicious of communication coming from the top. The managers at the top feel more responsibility towards organizational goals than those employees at the bottom, who feel very little responsibility. The relationship between superior and subordinate in this style resembles that of master-servant.

Style III: Consultative- Here, Motivation of workers is gained through rewards, occasional punishments, and very little involvement in making decisions and goals. Lower-level employees, in this system, have the freedom to make specific decisions that will affect their work. Upper-management still has control over policies and general decisions that affect an organization. Managers will talk to their subordinates about problems and action plans before they set organizational goals. Communication in this system flows both downward and upward, though upward is more limited. This promotes a more positive effect on employee relationships and allows them to be more cooperative. Lower-level employees are seen as consultants to decisions that were made and are more willing to accept them because of their involvement.

Style IV: Participative (Democratic)- Likert argued that the participative system was the most effective form of management. This system coincides with human-resources theory. This system promotes genuine participation in making decisions and setting goals through free-flowing horizontal communication and tapping into the creativity and skills of workers. Managers are fully aware of the problems that go on in the lower-levels of the organization. All organizational goals are accepted by everyone because they were set through group 
participation. There is a high level of responsibility and accountability of the organizational goals in all of the employees.

\section{Methodology}

\subsection{Research Design}

The study utilized the survey research design. Specifically, the cross sectional survey research design was adopted. A cross-sectional survey collects data to make inferences about a population of interest at one point in time. The relevant information on the relationship between work-related values of subgroups in Nigeria and leadership style was elicited from the sampled respondents.

\subsection{Population of the Study}

This study focused on the Yoruba subgroup cultures in Nigeria as they affect management. To this end, the population of the study comprises of all the staff of Central Bank of Nigeria. From the data obtained from Head of Human Resources Department of the bank on the $1^{\text {st }}$ of July, 2013, there was 2,515 staff of Central Bank of Nigeria at the Headquarters.

\subsection{The Sample Size and Sampling Technique}

Since the population is known $(2,515)$, sample size for the study was determined using Yameni's formula as stated below:

$$
\mathrm{n}=\frac{\mathrm{N}}{1+\mathrm{N}(0.05)^{2}}
$$

Where: $\mathrm{n}=$ Sample size, $\mathrm{l}=$ Constant Value, $\mathrm{N}=$ Population Size= Coefficient of Confidence or error terms (0.05).

Therefore, a sample size of 345 was used. Purposive sampling method was used in selecting employees of Central Bank of Nigeria from three geo-political zones of Nigeria.

\subsection{Method of Data Analysis}

The data that were generated from the use of structured questionnaire were analyzed using descriptive statistics such as simple percentage and frequency table. In line with the objectives of the study, power distance index (PDI), and individualism/collectivism index (IDV) were computed using the formulae developed by Hofstede.

The formula that was used to compute PD1=135-a+b-25c

Where: $\mathrm{a}=$ the percentage 'Manager 3 ' in question $40, \mathrm{~b}=$ the percentage 'Manager 1 ' plus 'manager 2' in question 41 and $\mathrm{c}=$ the mean score on question 43.

The formula that was used to calculate IDV $=76 \mathrm{~m} 4-43 \mathrm{~m} 1=30 \mathrm{~m} 8-27 \mathrm{~m} 13-29$

$1=$ mean score of question 24_1, 4 = mean score of question 24_4.

8 = mean score of question 24_8, 13 = mean score of question 24_13

Pearson Correlation was employed to examine the relationship between leadership styles and subgroup cultures. All the analysis was conducted with the aid of statistical Package for Social Science (SPSS).

\section{Data Presentation, Analysis and Interpretation}

The demographic information of the respondents sampled for this study is presented in Table 4.1 below, as follows:

Length of working experience: From Table 4.1, it can be deduced that majority of the respondents (58.92\%) have spent substantial years (5-20) in the CBN.

Respondents' age: A critical look at the Table 4.1. It can be deduced that majority of the staff of the CBN (56.93\%) are still within their youthful and vibrant age (Less than 40years). 
Year of formal school education: A close look at Table 4.1 reveals that the respondents have above 13 years of formal school education as shown by $67.54 \%$ for the Yoruba's.

Academic/Professional Qualifications: $68.42 \%$ have first degree qualifications, $11.40 \%$ have master's degree qualification. $20.18 \%$ have doctorate qualification. Summarily, it can be deduced that majority of the sampled respondents are individuals with high level of formal educations which is critical to the financial sector such as the CBN.

Respondents' religion: A summary from the table reveals, $73.58 \%$ of the respondents are Christian while $20.44 \%$ are Muslim and $5.98 \%$ practice African traditional worship and other religions.

Table 1: Demographics of Respondents

\begin{tabular}{|c|c|c|c|c|}
\hline \multirow[b]{2}{*}{ Sample Size } & \multicolumn{2}{|c|}{ YORUBA } & \multicolumn{2}{|c|}{ NATIONAL } \\
\hline & Freq & $\%$ & Freq & $\%$ \\
\hline \multicolumn{5}{|c|}{ Length of Working Experience } \\
\hline Less than five years & 28 & 25 & 110 & 33.33 \\
\hline Five years to twenty years & 66 & 58.92 & 163 & 49.39 \\
\hline More than twenty years & 18 & 16.07 & 57 & 17.27 \\
\hline Total & 112 & 100 & 330 & 100 \\
\hline \multicolumn{5}{|c|}{ Respondents' Age } \\
\hline Less than forty years & 70 & 61.95 & 193 & 56.93 \\
\hline More than forty years & 43 & 38.05 & 146 & 43.09 \\
\hline Total & 113 & 100 & 339 & 100 \\
\hline \multicolumn{5}{|c|}{ Year of Formal School Education } \\
\hline Less than 13 years & 37 & 32.46 & 81 & 23.97 \\
\hline 13 years and above & 77 & 67.54 & 257 & 76.04 \\
\hline Total & 114 & 100 & 338 & 100 \\
\hline \multicolumn{5}{|c|}{ Academic/Professional Qualifications of Respondents } \\
\hline First Degree & 78 & 68.42 & 101 & 29.89 \\
\hline Master Degree & 13 & 11.4 & 47 & 13.91 \\
\hline Doctorate Degree & 23 & 20.18 & 190 & 56.21 \\
\hline Total & 114 & 100 & 338 & 100 \\
\hline \multicolumn{5}{|c|}{ Respondents' Religion } \\
\hline Islam & 26 & 23.64 & 65 & 20.44 \\
\hline Christianity & 71 & 64.55 & 234 & 73.58 \\
\hline African traditional worship & 8 & 7.27 & 11 & 3.46 \\
\hline Others & 5 & 4.55 & 8 & 2.52 \\
\hline Total & 110 & 100 & 318 & 100 \\
\hline
\end{tabular}

Source: Researcher's Field Work (2015)

\subsection{Power Distance}

One of the objectives of this study was to determine the scores of the Nigerian subgroups in Hofstede's culture dimension of power distance. Power distance as a characteristic of a culture measures the extent to which individuals accept that power in an organization is 
unequally distributed. In calculating the power distance index for the subgroups (Yoruba) in Nigeria, the formula developed by Hofstede (1980) and used by Iguisi (2012, p.161) was adopted. Calculation of power distance index uses the following formula:

$$
\mathrm{PDI}=135-\mathrm{a}+\mathrm{b}-25 \mathrm{c}
$$

Where $\mathrm{a}=$ the percentage 'Manager 3 ' in question $40, \mathrm{~b}=$ the percentage 'Manager 1 ' plus 'Manager 2' in question 41 and $\mathrm{c}=$ the mean score on question 43

Power Distance Indices (PDI) for Yoruba Subgroups are shown below;

PDI for Yoruba is: $135-25.7+(34.5+21.8)-25(3.351)=82$

PDI for National is: $135-29.1+(35.4+27.7)-25(3.277)=87$

\subsection{Individualism/Collectivism}

The objective of determining the scores of Nigerian subgroups in Hofstede's dimension of Individualism/collectivism was addressed here. Individualism/collectivism dimension revolves around the relative closeness of the relationship between individuals in a society. Using the data collected, and formula developed by Hofstede in calculating the individualism index (IDV), the IDV scores for the Yoruba subgroup was identified as follows:

$$
\text { IDV }=76 m 4-43 m 1+30 m 8-27 m 13-29
$$

1 = mean score of question 24_1. "Have sufficient time left for your personal or family life"

4 = mean score of question 24_4. "Have good physical working condition"

$8=$ mean score of question 24_8. "Work with people who cooperate well with each other" 13 = mean score of question 24 _ 13 . "Live in an area desirable to you and your family" Individualism Indices (IDVs) for Yoruba Subgroups are shown as follows: IDV for Yoruba is: 76(2.117) $-43(2.066)+30(2.183)-27(2.308)-29=46$

IDV for National is: $76(1.914)-43(2.009)+30(1.939)-27(2.093)-29=32$

Table2: Yoruba Subgroup Scores in Hofstede's Dimensions of Culture

\begin{tabular}{|c|c|c|}
\hline Subgroup & $\begin{array}{c}\text { Power Distance Index } \\
\text { (PDI) }\end{array}$ & $\begin{array}{c}\text { Individualism } \\
\text { Index (IDV) }\end{array}$ \\
\hline Yoruba & 82 & 46 \\
\hline
\end{tabular}

Source: Researcher's Fieldwork (2015)

The above computation shows that the Yoruba exhibited high power distance (82) Table 2 shows that Yoruba (46) is rated in the individualism score.

Table 3: Comparison of Nigerian Scores with Hofstede's Dimensions of Culture

\begin{tabular}{|c|c|c|}
\hline Subgroups & $\begin{array}{c}\text { Power Distance } \\
\text { Index (PDI) }\end{array}$ & $\begin{array}{c}\text { Individualism } \\
\text { Index (IDV) }\end{array}$ \\
\hline Nigeria-Present Study & 87 & 32 \\
\hline Nigeria-Iguisi (2012) & 100 & 46 \\
\hline Hofstede (WAF Region-1991) & 77 & 20 \\
\hline Difference (Present Study \&lguisi) & -13 & -14 \\
\hline Difference (Present Study \&Hofstede) & +10 & +12 \\
\hline
\end{tabular}

Source: Researcher's Fieldwork (2015)

Table3, shows the scores obtained by Hofstede, Iguisi and the present study. The power distance score in this study for Nigeria nationally is 87 . This score lies between the scores obtained by Hofstede, 77 and Iguisi 100. According to Iguisi (2012) the difference between Hofstedes score and his score was due to modernization. The difference in the scores obtained in Iguisi's study and the present study is -13 while that of Hofstede's study and the 
present study is +10 . One of the likely reasons for the difference $(-13)$ in power distance score between this present study and the study conducted by Iguisi (2012) may be due to the monumental growth in information and communication technology. These days, the availability of different social media platforms such as Facebook, Instagram, Twitter, WhatsApp, among others have greatly closed the communication gap between boss and subordinates. These platforms provide for a friendlier interaction among organizational members. Also the literacy level shown in demographic respondents table 4.1 reveals that $78.4 \%$ of the total respondents have at least 13 years of formal school education. Education has further improved and enhanced the modernization process thus reducing power distance. Furthermore, the organization used for this study between the present and Iguisi's own have different organizational culture. Iguisi studied a cement industry which is a private sector organization where high power distance score might be recorded higher than that of the central bank of Nigeria used in the present study which is a public sector organization. The factor responsible for this high power distance is expressed in the relationship between the Boss and subordinates which appears more formal in private organization than in public organization.

The National score as presented in Table 4.3, 32 for IDV is greater than that of Hofstede (WAF Region) but less than that of Iguisi (2012) score of 46 . The difference in the score obtained in Iguisi's study and the current study is -14 while that of Hofstede study and the current study is +12 . In spite of the variation in scores, the studies indicate that Nigeria is a collective society as it scored 32 in the individualism scale which is low. Having a collectivist culture, Personal opinions hardly exist as people constantly seek the ideas and opinions of the group to which they belong.

From the Table 4.3, the value of PDI for the different subgroup cultures have a number of implications on management practices. Firstly, workforces in high power distance societies are accustomed to, depending on their supervisors for direction and decision-making.

Finally, subordinates in low power distance cultures expect superiors to consult them and approach superiors to express their point of view on matters of relevance to the job or employee. They therefore have opportunities to develop closer relationships with superiors compared to employees in cultures high in power distance.

\section{Leadership styles among the Yoruba Subgroups.}

"The success or failure of an organization depends to a large extent on the quality of the leader and the leadership style the leader adopts in managing the organization, and on the acceptance of this leadership style by the followers" (Iguisi, 2012; p.173). In establishing the preferred leadership style of employees, four types of leaders were named. The results of the analysis are presented in Table 4 below:

Table 4: Types of Leaders (Preferred, perceived and Rejected)

\begin{tabular}{|l|c|c|c|}
\hline Leadership styles & Preferred (\%) & Perceived (\%) & Rejected (\%) \\
\hline Autocratic & 14.7 & 34.5 & 46.4 \\
\hline Paternalistic & 16.5 & 21.8 & 26.4 \\
\hline Consultative & 25.7 & 30.9 & 16.4 \\
\hline Democratic & 43.1 & 12.7 & 10.9 \\
\hline
\end{tabular}

Source: Researcher's Fieldwork (2015) 
Tables 4 reveals that Yoruba subgroups, democratic leadership style $(43.1 \%)$ is the most preferred; followed by consultative leadership style (25.7\%) the autocratic leadership style is perceived to be the most dominant and autocratic leadership style (46.4\%) is the most often rejected.

\subsection{Leadership Style and Yoruba Subgroup Cultures}

Pearson Correlation was conducted to establish the relationship between the scores of the subgroups (Yoruba) in the Hofstede dimension of cultures (Power distance and individualism/collectivism) and leadership styles preferred, perceived and rejected. The summary of the results is presented in Table 5 below:

Table 5: Pearson correlation result.

\begin{tabular}{|c|c|c|c|c|c|c|}
\hline \multicolumn{7}{|c|}{ Correlations } \\
\hline & & $\begin{array}{c}\text { Power } \\
\text { Distance }\end{array}$ & $\begin{array}{l}\text { Individ } \\
\text { ualism }\end{array}$ & $\begin{array}{c}\text { Preferred } \\
\text { Leadership } \\
\text { Style } \\
\end{array}$ & $\begin{array}{c}\text { Perceived } \\
\text { Leadership } \\
\text { Style } \\
\end{array}$ & $\begin{array}{l}\text { Rejected } \\
\text { Leadership } \\
\text { Style }\end{array}$ \\
\hline \multirow{3}{*}{$\begin{array}{l}\text { Power } \\
\text { Distance }\end{array}$} & $\begin{array}{l}\text { Pearson } \\
\text { Correlation }\end{array}$ & 1 & .206 & -.007 & -.092 & -.205 \\
\hline & Sig. (2-tailed) & & .033 & .944 & 340 & .032 \\
\hline & $\mathrm{N}$ & 325 & 108 & 108 & 109 & 109 \\
\hline \multirow{3}{*}{ Individualism } & $\begin{array}{l}\text { Pearson } \\
\text { Correlation }\end{array}$ & $.206^{*}$ & 1 & .009 & .093 & -.066 \\
\hline & Sig. (2-tailed) & .033 & & .929 & .340 & .499 \\
\hline & $\mathrm{N}$ & 108 & 109 & 108 & 107 & 107 \\
\hline \multirow{3}{*}{$\begin{array}{l}\text { Preferred } \\
\text { Leadership } \\
\text { Style }\end{array}$} & $\begin{array}{l}\text { Pearson } \\
\text { Correlation }\end{array}$ & -.007 & .009 & 1 & $.393^{\pi}$ & .015 \\
\hline & Sig. (2-tailed) & .944 & .929 & & .000 & .875 \\
\hline & $\mathrm{N}$ & 108 & 108 & 109 & 108 & 108 \\
\hline \multirow{3}{*}{$\begin{array}{l}\text { Perceived } \\
\text { Leadership } \\
\text { Style }\end{array}$} & $\begin{array}{l}\text { Pearson } \\
\text { Correlation }\end{array}$ & -.092 & .093 & $.393^{n}$ & 1 & $.272^{n}$ \\
\hline & Sig. (2-tailed) & .340 & .340 & .000 & & .004 \\
\hline & $\mathrm{N}$ & 109 & 107 & 108 & 110 & 109 \\
\hline \multirow{3}{*}{$\begin{array}{l}\text { Rejected } \\
\text { Leadership } \\
\text { Style }\end{array}$} & $\begin{array}{l}\text { Pearson } \\
\text { Correlation }\end{array}$ & $-.205^{\wedge}$ & -.066 & .015 & $.272^{n}$ & 1 \\
\hline & Sig. (2-tailed) & .032 & .499 & .875 & .004 & \\
\hline & $\mathrm{N}$ & 109 & 107 & 108 & 109 & 110 \\
\hline
\end{tabular}

The correlation results depicted in Table 5 showed that there is no positive and significant relationship between the scores of Yoruba subgroup in the Hofstede dimension of individualism/collectivism, and the leadership styles preferred and perceived.

\section{Discussion of Findings}

Firstly, this study found that there is a high power distance among the subgroup (Yoruba) in Nigeria. The power distance scores obtained from the analysis of data from the responses of the organizational members used for this study revealed that the Yoruba which constitute 
the subgroups for analysis in Nigeria have a high power distance. This implies that there is great inequality in power distribution among the Yoruba's, matching it against the case study (Central Bank of Nigeria), the answer still remains the same, the Yoruba's have high respect for their Superiors even at work, but using the framework of leadership, the Yoruba preferred the democratic style of leadership. It is the belief of the Yoruba respondents that having a manager or boss or direct superior one can respect is important but such manager must use democratic approach in his decision making process concerning the subordinates' work.

High power distance scores has a number of implications. It leads to dependent on the power holder. This could result in subordinates not taking own initiative, but rather wait for the boss to give instructions. There is also relatively little real empowerment. Iguisi (2004) has earlier indicated that ethnic affiliation often leads to discriminatory work allocation in Nigerian workplace, the collectivistic nature of the Yoruba displays collectivism especially when they meet outside their immediate community. They believe in rallying around one another most especially on social occasion.

The low individualism score reported in this study is not a surprising result as the influence of tribe, ethnicity and family in African culture, is in indeed very strong and overwhelming (Iguisi, 2012). A large part of African motivation is to serve his or her immediate and extended family financially; hence they see the organization as functional rather than existential. As the Nigerian managers achieve more seniority, they feel more "involved" with the organization, that is, they do not treat it as instrumental in providing their material needs. Based on this study data, the democratic leadership style is the most strongly preferred and the autocratic style the most strongly rejected at the National level analysis. The implication is that the leaders from these subgroup cultures would be more effective if they exhibit the attributes of democratic leadership style. This finding collaborates Awujo's (1988) study that showed that leaders need to provide guidance without pressure as most workers or subordinates enjoy frequent and supportive communication from their leaders.

With respect to one the findings of the study that showed that there is positive and significant relationship between the scores of Yoruba in the Hofstede dimension of power distance and the leadership styles preferred, Pascale (1978) argued that participative decision making is more prevalent in low power distance culture compared to non-participative approach being more prominent within high power distance culture. Similarly, Hofstede (2001) found that in low power distance culture, managers consider their subordinates' suggestions before taking any final decisions whilst in high power distance culture, only managers are involved in that process. Iguisi (2004) asserted that African society generally is very paternalistic and hierarchical. Little prone to individualism, it tends to be egalitarian within the same age group but hierarchical in group-to-group relations, with marked subordination of the younger members, which are expected to give absolute loyalty as children are assumed to give their father. The paternalistic component confers on management the right to give orders and exact obedience and impose sanctions (Iguisi, 2004).

Comparing these findings to other relevant African culture, the authors noticed that the Fulani/Hausa's in similar studies has high power distance as they give utmost respect to their superiors in organizations, and also there is high collectivism, as they tend to behave as one. However, despite the high respect for their boss, they prefer the consultative leadership style. So superiors in these types of organization settings ought to consult with their employees. The Igbo's has high power distance, but low on collectivism and high on individualism, that's why the Igbo when found in an organization don't rally among themselves, and when it comes to leadership styles they also prefer the Consultative leadership style just like the Hausa/Fulani's. These comparisons are based upon the works of Iguisi (2004) 


\section{Conclusion}

The findings of this study are evident from the responses obtained which revealed that Yoruba that constitutes a subgroup culture in Nigeria have high power distance. The Yoruba respondent share the opinion of having a boss or direct superior one can respect is pertinent but the leader must consult his subordinate in his decision making. The analysis of the leadership preference also show that the Yoruba's preferred the democratic leadership style. Nationally, it appears that democratic and consultative leadership styles are dominantly preferred by the Yoruba subgroup cultures.

Also these findings have contributed to existing knowledge which are outlined below,

i. Iguisi (1994) study on culture dimension in Nigeria was on the cement industry. This study extended knowledge on cultural dimension in Nigeria to the financial sector;

ii. Awujo (1988) study found that managers from the West are more democratic than managers from the North and managers from the East are less Democratic. Our study support this findings being that Yoruba sub-culture preferred democratic leadership style.

iii. The study has added to knowledge by showing that high power distance societies are characterized by autonomy as subordinates depend heavily on their supervisors for direction and decision-making. Employees are not encouraged to make suggestions and do not expect to be consulted or empowered; they expect to be told what to do and avoid disagreement.

\section{References}

Aluko, M.A.O., 2003. The Impact of culture on organizational performance in selected textile firms, in Nigeria.Nordic Journal of African Studies, 12(2), pp.164-179.

Awujo, A.C., 1988. A study of managerial attitudes in Nigeria. Journal of Management Education and Training, 3(2), pp.115.

Hofstede, G.,1980. Motivation, leadership and organization: Do American theories apply abroad? Organizational Dynamics, pp.42-63.

Hofstede, G., 1984. Dimensions of culture in management and planning. Asia Pacific Journal of Management, 2(5), pp.23-35.

Hofstede, G. and Minkov, M., 2010. Cultures and Organizations: Software of the Mind. Asia Pacific Business Review, 16(4), pp.493-504.

Hosefede, G., 1997. Culture Definition, Measuring Cultural Differences.[online] Available at: http://people.tamu.edu/ i-choudhury//culture.html [Accessed 12 February 2016].

Iguisi, O., 1994. Appropriate management in an African culture. Journal of Management in Nigeria, 30(1), pp.16-24.

Iguisi, O.V., 2004. Cultures and feasible management practices in African organizations. Journal of Management in Nigeria, 3(2), pp.87-100.

Iguisi, O.V., 2009. Motivation-related values across cultures. African Journal of Business Management, 3(4), pp.141-150.

Iguisi, O.V., 2012. Modernity versus tradition in African management: The cultural dynamics of a management practice. African Management Research, 2(3), pp.32-42.

Likert, R., 1967. Coordination and organization. New York: McGraw Hill. [online] Available at:<https://vdocuments.mx/documents/coordination-and-organizational-design.html $>$ and < http://mgmt.iaufb.ac.ir/article 32076 806ca5b5c30f04016e183d4207572cd3.pdf>

[Accessed 11 November 2016].

Makama, G.A., 2013. Patriarchy and gender inequality in Nigeria: the way forward. European Scientific Journal, 9(17), pp.115-123. 
Pascale, R. T., 1978. Communication and decision making across cultures: Japanese and American comparisons. Administrative Science Quarterly, 23(5), pp.91-110.

\section{Bio-note}

Dr. Bello Deva Vincent is a senior lecturer in the Department of Management Technology, Yola. Modibbo Adama University of Technology Yola, Nigeria. His research interest and area of specialization are Human Resource Management and General Management.

Dr. Osarumwense V. Iguisi is a senior lecturer in the Department of Human Resource Management, Faculty of Management Science, University of Benin, Benin City. His research interest and area of specialization is Human Resource Management. 